\title{
Techno-Economic Analysis of Biodiesel Production from Microbial Oil Using Cardoon Stalks as Carbon Source
}

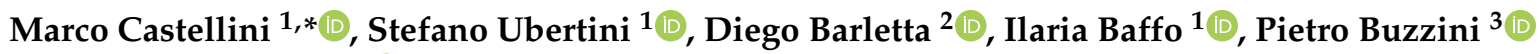 \\ and Marco Barbanera ${ }^{1}$ (D) \\ 1 Department of Economics Engineering Society and Business Organization (DEIM), University of Tuscia, \\ Largo dell'Università s.n.c., Loc. Riello, 01100 Viterbo, Italy; stefano.ubertini@unitus.it (S.U.); \\ ilaria.baffo@unitus.it (I.B.); m.barbanera@unitus.it (M.B.) \\ 2 Department of Industrial Engineering, University of Salerno, 84084 Fisciano, Italy; dbarletta@unisa.it \\ 3 Department of Agricultural, Food and Environmental Sciences, University of Perugia, Borgo XX Giugno 74, \\ 06121 Perugia, Italy; pietro.buzzini@unipg.it \\ * Correspondence: marco.castellini@unitus.it
}

check for updates

Citation: Castellini, M.; Ubertini, S.; Barletta, D.; Baffo, I.; Buzzini, P.; Barbanera, M. Techno-Economic Analysis of Biodiesel Production from Microbial Oil Using Cardoon Stalks as Carbon Source. Energies 2021, 14 1473. https://doi.org/10.3390/ en14051473

Academic Editor:

João Fernando Pereira Gomes

Received: 4 February 2021

Accepted: 5 March 2021

Published: 8 March 2021

Publisher's Note: MDPI stays neutral with regard to jurisdictional claims in published maps and institutional affiliations.

Copyright: (c) 2021 by the authors. Licensee MDPI, Basel, Switzerland. This article is an open access article distributed under the terms and conditions of the Creative Commons Attribution (CC BY) license (https:// creativecommons.org/licenses/by/ $4.0 /)$.

\begin{abstract}
Today one of the most interesting ways to produce biodiesel is based on the use of oleaginous microorganisms, which can accumulate microbial oil with a composition similar to vegetable oils. In this paper, we present a thermo-chemical numerical model of the yeast biodiesel production process, considering cardoon stalks as raw material. The simulation is performed subdividing the process into the following sections: steam explosion pre-treatment, enzymatic hydrolysis, lipid production, lipid extraction, and alkali-catalyzed transesterification. Numerical results show that $406.4 \mathrm{t}$ of biodiesel can be produced starting from 10,000 $\mathrm{t}$ of lignocellulosic biomass. An economic analysis indicates a biodiesel production cost of $12.8 \mathrm{USD} / \mathrm{kg}$, thus suggesting the need to increase the capacity plant and the lipid yield to make the project economically attractive. In this regard, a sensitivity analysis is also performed considering an ideal lipid yield of $22 \%$ and $100,000 \mathrm{t}$ of lignocellulosic biomass. The biodiesel production costs related to these new scenarios are 7.88 and $5.91 \mathrm{USD} / \mathrm{kg}$, respectively. The large capacity plant combined with a great lipid yield in the fermentation stage shows a biodiesel production cost of $3.63 \mathrm{USD} / \mathrm{kg}$ making the product competitive on the current market of biofuels by microbial oil.
\end{abstract}

Keywords: microbial oil; yeast biodiesel; cardoon stalks; production cost; sensitivity analysis

\section{Introduction}

The production of biodiesel or oleochemical precursor starting from varied vegetable oils, such as rapeseed, soybean, palm, peanut, sunflower, and waste cooking oils, is a promising alternative to fossil-based fuels. However, it increasingly requires attention in economic and environmental terms [1-3]. Due to the growing demand for biofuel production, it has become evident that other renewable resources (especially non-vegetable oils) should be imminently considered so that there is not competition with food production [4].

Biodiesel production using microbial oil, involving very different raw materials and representing a sustainable and energetically favorable process, has significantly involved recent research activities [5-9]. Microbial oil, also known as single cell oil (SCOs), is accumulated by oleaginous microorganisms during a fermentation process and using a variety of carbon substrates, including glucose, xylose, acetic acid, glycerol, and ethanol [10]. In particular, oleaginous yeasts show promising characteristics as for example their rapid growth rate and high lipid contents (up to $60 \%$ of their cell dry weight) when subjected to specific operating conditions [11-13]. Moreover, they have obvious advantages if compared to conventional vegetable oils thanks to their short life cycle and very low farm land use [14].

The accumulated microbial oil is primarily made of triacylglycerols (TAG) with fatty acid composition rich in C16 (e.g., palmitic and palmitoleic acids) and C18 (e.g., stearic, 
oleic, linoleic, and a-linoleic acids) [15,16], similarly to vegetables oils, and can be considered a good candidate to be used as a precursors of biodiesel [17]. The chemical process for biodiesel production, commonly known as transesterification, involves a reaction in which the glycerol group of triacylglycerol is replaced with a short-chain alcohol. Several methods are proposed in literature for this transesterification reaction [3,18-21].

In addition to vegetable oils, the attention of the research community is also focused on alternative and definitely cheaper carbon sources for microbial oil accumulation by oleaginous yeasts, such as agro-industrial wastes and non-food crops [22]. Different pre-treatments are effective on the lignocellulosic biomasses to make more accessible carbohydrates, thus facilitating the yeast growth and lipid accumulation [23]. However, this preliminary chemical transformation of the feedstock introduces degradation products that may influence the correct yeast growth and metabolism [24]. Based on these considerations, recent authors have reported the necessary operating conditions to optimize the lipids production process, evaluated for different kinds of lignocellulosic biomass [25]. In this context, Cardoon (Cynara cardunculus), a wild robust perennial plant native to the Mediterranean region [26], represents a very interesting medium to the oil production starting from its marginal residues [27]. Cardoon is not cultivated as a food crop [28] but shows high growth rates (i.e., $10-12 \mathrm{t} / \mathrm{ha}$ from Italians cultivations) $[29,30]$ together with low water and nutrients consumption. Therefore, it can be successfully associated with lignocellulosic biorefinery approach [31]. Unlike common agricultural crops, cardoon can grow in hostile soils and therefore severely limit the occupation of land dedicated to the cultivation of food products.

The biorefinery performance has been widely studied in the literature $[32,33]$ through productivity analyses, energy balances, and techno-economic evaluations for different process configurations, often employing Aspen Plus Software [34-36]. However, to the best of authors' knowledge, the entire production process of microbial biodiesel has not been studied so far. The development of appropriate and meticulous simulations, as reported by Garcia et al. [37], allows defining the economic feasibility and establishing the best operating conditions for a biorefinery process. Barletta et al. [38] simulated the flowsheet resulting from the economic optimization procedure of the lignocellulosic biorefinery superstructure. Meramo et al. [39] proposed a conceptual design of a biorefinery system from corn residues with the aim of reducing the accumulation of solid waste and producing bioethanol and succinic acid. To correctly model a microbial oil production as a renewable resource for biodiesel, it is necessary to know data and information related to kinetics and thermodynamics of the reactions in each step of the designed process [40,41]. From this perspective, several studies carried out in the literature adopted different assumptions for making the preliminary design of industrial plant. Koutinas et al. [42] calculated material balances by assuming two diverse stages during lipid fermentation based on stoichiometric equations in which the stoichiometric coefficients derived from experimental results [43]. Humbird et al. [44], in their report for biochemical conversion of lignocellulosic biomass to ethanol, available from the National Renewable Energy Laboratory (NREL), modeled the process using bioreactors with conversions of specific reactions determined on lab scale. The components and the physical properties of some of the solid constituents of lignocellulosic biomass and the fermentation process were taken from the NREL database for biofuels components [45].

Some researchers have explored the techno-economic feasibility of biodiesel production from microbial oil produced by microorganisms through the fermentation of glucose-based media [42,46,47].

In this paper, we develop a model of the entire microbial oil production process. The present research is the first attempt to develop a realistic simulation and to evaluate the design and techno-economic viability on industrial scale of the microbial oil production process as a renewable resource for biodiesel production starting from agro-industrial wastes such as cardoon stalks. The process is based on the use of Leucosporidium creatinivorum DBVPG 4794, a non-conventional yeast able to use both glucose and xylose as 
carbon substrates. Previous experimental results obtained by the authors for cardoon stalks composition, its cellulose enzymatic hydrolysis, and lipid fermentation were used, in order to obtain a more realistic analysis [22].

The remaining part of the paper is organized as follows: Section 2 reports the assumptions adopted to perform the design of the process, by focusing on the main phases, such as biomass pre-treatment, enzymatic hydrolysis, lipid production, lipid extraction, and biodiesel production. Section 3 provides the feasibility of the system in terms of mass and energy balances and economic analysis. Section 4 presents the concluding remarks.

\section{Materials and Methods}

\subsection{Process Simulation}

The process simulation software, Aspen Plus [34] v10, is used to develop the entire biorefinery process for biodiesel production starting from a microbial oil and to calculate its mass and energy balances including the utility requirements. The simulation of a generic chemical process requires defining chemical components, selecting a thermodynamic model, modeling the process flowsheet, and setting up the operating conditions of all feed streams and unit operation models [48]. The NRTL (non-random two liquids) thermodynamic model is appropriately selected for extraction routes simulation on the basis of its good representativeness of polar mixtures in phase equilibrium calculations [3]. Moreover, it is used to calculate most of the binary interaction coefficients, taking the missing values from Humbird et al. [44]. UNIF-DMD (UNIFAC with Dortmund correction) method is instead used for the extraction of water and glycerol [49], and the Henry's law is used to designate the non-condensable components (e.g., oxygen, nitrogen, and carbon dioxide) in the liquid phase. Conventional chemicals and unconventional compounds are defined using the Aspen Plus internal database and NREL component definitions [44] or literature data [42]. Each chemical transformation process is carried out in stoichiometric reactor blocks (RStoic) where mass balance calculations are associated with the extent of chemical reactions, but not with the kinetic behavior. Liquid-solid separation is performed via centrifuge filter blocks (CFuge) using the Stokes sedimentation model and the Shubert deliquoring model [48]. The Winn-Underwood-Gilliland method [50] (DSTWU module) is used to obtain initial estimates about the performance of distillation columns for the rigorous methods such as RadFrac module, the main block for simulating all types of multistage vapor-liquid fractionation operations in Aspen Plus. Column design is accompanied by the consideration of pressure drops between boiler and condenser correlated to the theoretical number of stages. Calculator blocks with Fortran language and design specifications are implemented to set the desired process parameters.

The simulation considers a plant capable of processing 10,000 t/year lignocellulosic biomass with 8000 operating hours per one year. The designed facility is based on lab-scale experimental results. Various organic streams of by-products are considered to produce steam and electricity to make the plant totally self-sufficient in energy. The combustor and turbogenerator subsystem are modeled with a simplified approach. Hot streams such as high-pressure steam and flash steam transfer a large part of their thermal content through counter-current heat exchangers simulated with a minimum temperature approach of $1^{\circ} \mathrm{C}$ and a shortcut configuration.

The economic analysis, based on the 2017 U.S. dollars, is conducted to calculate discounted cash flow and to evaluate profitability for the modeled scenario employing Aspen Plus Economic Analyzer (Aspen PEA) v10 software [44,48]. The wastewater treatment area, although not developed in the current project, is appropriately taken into account in operating costs [42].

Cardoon stalks composition used for the simulation, shown in Table 1, was based on data determined experimentally for cardoon stalks produced in Italy [51]. The evaluation of extractives content was carried out by water/ethanol extraction. Due to lack of information, protein amount is inserted considering corn stover composition [44]. 
Table 1. Cardoon stalks composition used for process simulation.

\begin{tabular}{cc}
\hline Component & Composition (Dry wt \%) \\
\hline Cellulose & 30.52 \\
Xylan & 14.52 \\
Mannan & 0.45 \\
Galactan & 1.06 \\
Arabinan & 1.15 \\
Acetate & 5.02 \\
Pectine & 4.67 \\
Lignin & 14.21 \\
Ash & 8.80 \\
Protein & 3.10 \\
Extractives & 16.51 \\
Moisture (bulk wt $\%)$ & 15.00 \\
\hline
\end{tabular}

To correctly manage solids handling in Aspen Plus, it is necessary define a particle size distribution (PSD) expressed in terms of the mean particle size $(35 \mathrm{~mm})$ and standard deviation $(5 \mathrm{~mm})$.

\subsubsection{Feed Handling and Steam Explosion Pre-Treatment}

Figure 1 shows the Aspen Plus flowsheet of feed handling and steam-explosion pretreatment in which each stream is accompanied by the corresponding temperature and mass flow rate values. The dashed red lines ( $\mathrm{H} 1, \mathrm{H} 2$, and $\mathrm{H} 3$ ) represent the path of the heat flow extracted from the combustion reactor (R5) as thermal content of the gas.

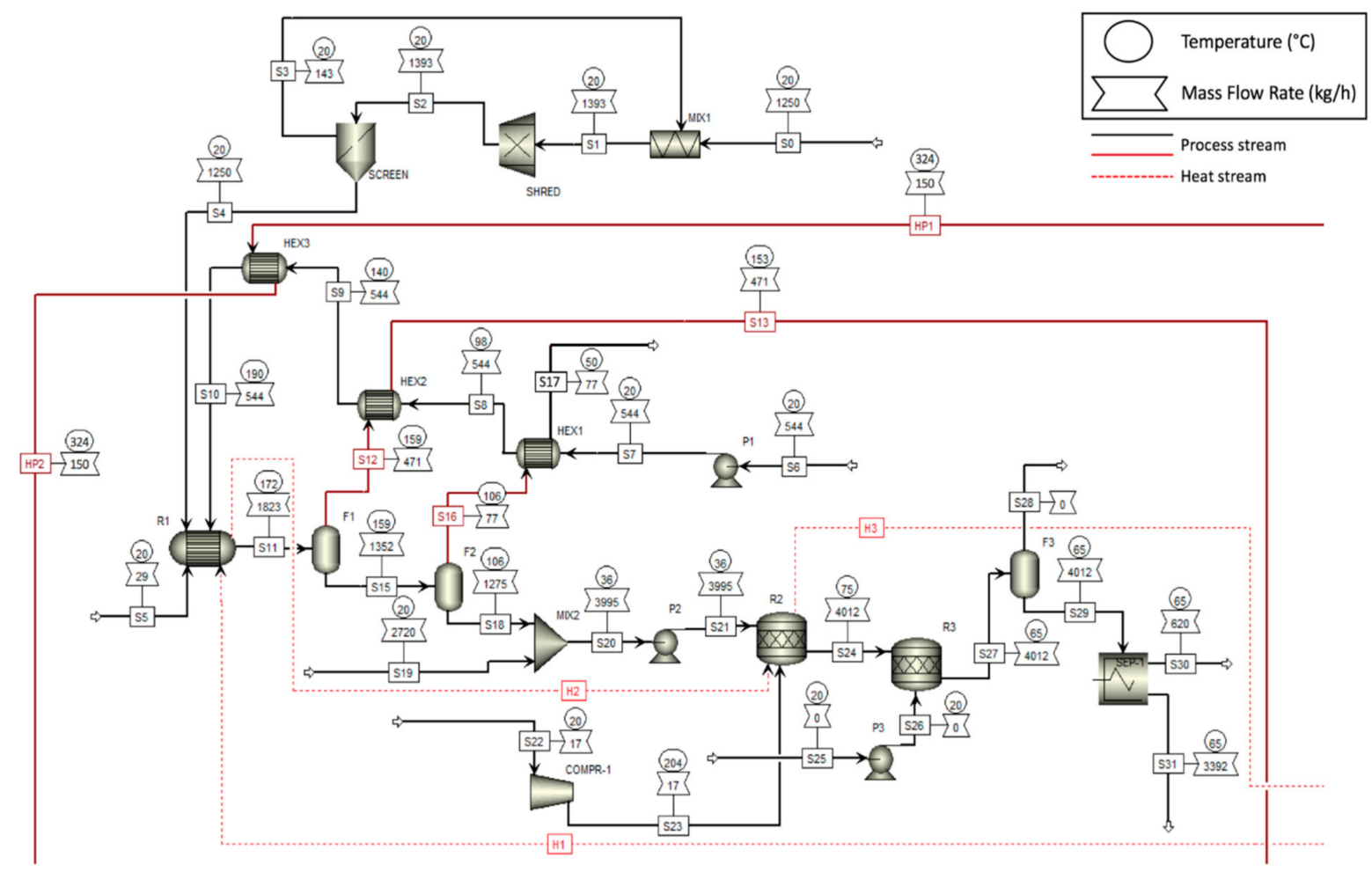

Figure 1. Flowsheet of feed handling and steam explosion pre-treatment as simulated using Aspen Plus. 
Feedstock (S0) is milled using a mechanical size reduction process such as a hammer mill [52]. This operation, simulated in Aspen Plus using a crusher block (SHRED) and selecting a screen size of $3.2 \mathrm{~mm}$, aims to increase the exposed surface area and so to improve the mass and energy transfer rates [53]. Milled feedstock is conveyed in a hydrothermal pre-treatment reactor (R1) and treated with a sulfuric acid (S5) loading of $0.025 \mathrm{~g} / \mathrm{g}$ dry biomass to convert much of the starting hemicellulose carbohydrates to soluble sugars by hydrolysis reactions and to break down the biomass for subsequent enzymatic hydrolysis. The steam flow (S10), originating from $0.512 \mathrm{~g}$ of process water/g dry biomass, is introduced into the pre-treatment reactor (R1) with high temperature $\left(190^{\circ} \mathrm{C}\right)$ and pressure $(22 \mathrm{~atm})$. The reactor, operating at $172{ }^{\circ} \mathrm{C}$ and $7 \mathrm{~atm}$, is simulated using a stoichiometric reactor block where the reaction yields are determined experimentally considering a residence time of $10 \mathrm{~min}$ and assuming that minor hemicellulose carbohydrates have the same reactions and conversions as xylan. Specifically, the reaction yields adopted generate a recovery of cellulose and hemicellulose in the hydrolysate slurry equal to $95.4 \%$ and $56.8 \%$, respectively. Reactions and their corresponding yields considered are given in Table 2.

Table 2. Conversion for reaction considered in the steam explosion pre-treatment (R1).

\begin{tabular}{ccc}
\hline Stoichiometry & Fractional Conversion of Component & Fractional Conversion \\
\hline Cellulose + Water $\rightarrow$ Glucose & Cellulose & 0.041 \\
Cellulose $\rightarrow$ HMF + 2 Water & Cellulose & 0.006 \\
Xylan + Water $\rightarrow$ Xylose & Xylan & 0.386 \\
Xylan $\rightarrow$ Furfural + 2 Water & Xylan & 0.075 \\
Mannan + Water $\rightarrow$ Mannose & Mannan & 0.386 \\
Mannan $\rightarrow$ HMF + 2 Water & Mannan & 0.010 \\
Galactan + Water $\rightarrow$ Galactose & Galactan & 0.386 \\
Galactan $\rightarrow$ HMF + 2 Water & Galactan & 0.010 \\
Arabinan + Water $\rightarrow$ Arabinose & Arabinan & 0.386 \\
Arabinan $\rightarrow$ Furfural + 2 Water & Arabinan & 0.075 \\
Acetate $\rightarrow$ Acetic Acid & Acetate & 1.000 \\
Lignin $\rightarrow$ Soluble Lignin & Lignin & 0.050 \\
\hline
\end{tabular}

Steam explosion pre-treatment at $172{ }^{\circ} \mathrm{C}, 7$ atm, and at 10 min of residence time.

The hydrolysate slurry (S11) is flash-cooled through two adiabatic flash blocks (F1 and F2) at 5 and $1 \mathrm{~atm}$, respectively, vaporizing a large amount of water along with some of acetic acid and of sugar degradation products such as furfural and 5-hydroxymthyl furfural. These flash vapors generated (S12 and S16) are used to partially heat the process water (S6) for hydrothermal pre-treatment [53]; the remaining thermal demand is satisfied with high-pressure steam (HP1) produced in a dedicated section of the plant.

A feed ratio of $4.8 \mathrm{~g}$ of ammonia gas (S22) per liter of hydrolysate, mixed into dilution water (S19), is used to raise $\mathrm{pH}$ from 1 to 5 in a conditioning reactor (R2) simulated as a stoichiometric reactor block with moderate temperature $\left(75^{\circ} \mathrm{C}\right)$ and a pressure of $5 \mathrm{~atm}$ [44]. A further stoichiometric reactor block (R3), operating at $65^{\circ} \mathrm{C}$ and $5 \mathrm{~atm}$, removes ammonia gas not converted by means of sulfuric acid (S25). Reactions and their corresponding yields considered are given in Table 3 . The pressure drop after the conditioning process is modeled in a flash unit (F3) block.

Table 3. Conversion for reaction considered in the neutralization (R2) and in the re-acidification (R3) processes.

\begin{tabular}{ccc}
\hline Stoichiometry & Fractional Conversion of Component & Fractional Conversion \\
\hline Acetic Acid + Ammonia $\rightarrow$ Ammonium-Acetate & Acetic Acid & 0.037 \\
Sulfuric Acid +2 Ammonia $\rightarrow$ Ammonium-Sulfate & Sulfuric Acid & 0.041 \\
Arabinose $\rightarrow$ TAR & Arabinose & 0.006 \\
Galactose $\rightarrow 1.2$ TAR & Galactose & 0.356 \\
Mannose $\rightarrow 1.2$ TAR & Mannose & 0.386 \\
Sulfuric Acid +2 Ammonia $\rightarrow$ Ammonium-Sulfate & Ammonia & 1.000 \\
\hline
\end{tabular}


At this point the liquid (S31) and solid fractions (S30) rich in depolymerized xylan and in lignocellulosic components, respectively, are then separated by a centrifuge filter (FILT-1).

\subsubsection{Enzymatic Hydrolysis}

Figure 2 shows the Aspen Plus flowsheet of enzymatic hydrolysis and combustion section. The dashed blue lines indicate the power flow generated by the multistage (T1 and T2) steam turbine.

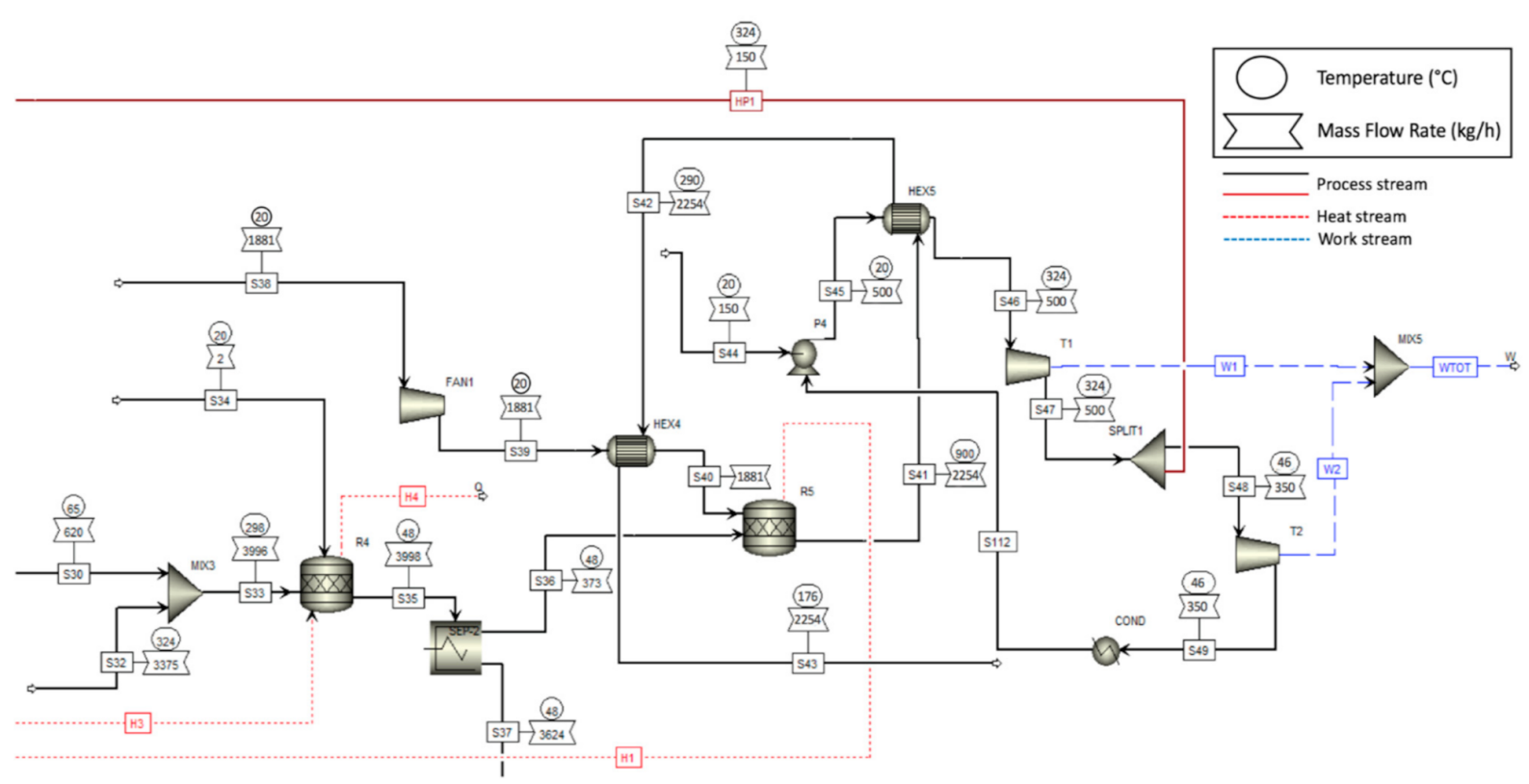

Figure 2. Flowsheet of enzymatic hydrolysis and combustion section as simulated using Aspen Plus.

The solid fraction (S30) is sent to the enzymatic hydrolysis reactor (R4), simulated with a stoichiometric block, where cellulose and hemicellulose are finally converted to hydrolyzed sugars using commercial enzyme (Cellic Ctec2, Novozymes, Denmark) and respecting precise working conditions $\left(50^{\circ} \mathrm{C}\right.$ and $\left.1 \mathrm{~atm}\right)$ [52]. The amount of enzyme used (S20) is determined based on dry biomass content (mostly cellulose and hemicellulose). In the present design, the total enzyme loading is $1.32 \mathrm{~g} / \mathrm{g}$ dry biomass to achieve a $73.9 \%$ and $74.8 \%$ conversion to glucose and xylose, respectively. It is assumed that the minor hemicellulosic sugars are converted into their corresponding hydrolysate sugars with the same yield and reaction as xylan. Reactions and their corresponding yields considered for enzymatic hydrolysis are given in Table 4.

Table 4. Conversion for reaction considered in the enzymatic hydrolysis (R4).

\begin{tabular}{ccc}
\hline Stoichiometry & Fractional Conversion of Component & Fractional Conversion \\
\hline Cellulose + Water $\rightarrow$ Glucose & Cellulose & 0.739 \\
Xylan + Water $\rightarrow$ Xylose & Xylan & 0.748 \\
Mannan + Water $\rightarrow$ Mannose & Mannan & 0.748 \\
Galactan + Water $\rightarrow$ Galactose & Galactan & 0.748 \\
Arabinan + Water $\rightarrow$ Arabinose & Arabinan & 0.748 \\
\hline
\end{tabular}


According to Humbird et al. [44], a temperature of $50{ }^{\circ} \mathrm{C}$ and an atmospheric pressure are maintained throughout the process to increase the enzyme activity. A process water steam (S32) is used to adjust the moisture content of the medium (S30) to $85 \%$ while potassium hydroxide (S20) and sulfuric acid (S20) are used to maintain the medium at $\mathrm{pH}$ 5. Once the conversion of major cardoon components to soluble sugars is complete, the slurry is filtered with a centrifuge filter (FILT-2) to separate the solid fraction (S36), rich in cellulose, and the lignin from the liquid fraction (S37), rich in hydrolysate sugars.

By-products such as all the lignin and the unconverted cellulose and hemicellulose from the feedstock (S36) are used for energy self-sufficiency of the plant and to reduce costs related to solid waste disposal. A combustion process able to manage a wet feed with moisture of $5 \%$ and considering an excess air equal to $10 \%$ is modeled with a stoichiometric reactor (R5). The air stream (S38) is moved into the combustion chamber (R5) by a fan (FAN1) after being pre-heated up $170{ }^{\circ} \mathrm{C}$ in a heat exchanger (HEX4). The thermal energy content of the gas (heat of combustion, H1) is removed [54] and used to thermally feed the reactors and the boiler. Flue gas (S41) at $900{ }^{\circ} \mathrm{C}$ is used to convert a treated feed water (S44) of $500 \mathrm{~kg} / \mathrm{h}$ to high pressure stream $\left(460^{\circ} \mathrm{C}\right.$ and $\left.60 \mathrm{~atm}\right)$ through a heat exchanger (HEX5) and to pre-heat the air stream (S39) with their residual energy content. The flue gas is anyway expelled in the atmosphere at high temperature (above $160{ }^{\circ} \mathrm{C}, \mathrm{S} 43$ ) to avoid corrosion phenomena due to the presence of potentially aggressive chemical compounds (e.g., sulphur dioxide). The generated high-pressure steam (S46) constitutes the working fluid of a multistage steam turbine (T1 and T2) operating at 65\% isentropic efficiency; $30 \%$ of the total steam (HP1) is extracted from the turbine at a particular thermodynamic condition $\left(324{ }^{\circ} \mathrm{C}\right.$ and $\left.20 \mathrm{~atm}\right)$ in order to be used in the biorefinery process, while the remaining part (S48) is expanded up to $0.1 \mathrm{~atm}$ in the second stage of the turbine to generate electricity (W2). The outlet stream (S49) is then condensed (COND) before being recycled.

The glucose-rich syrup (S37) is cooled to fermentation temperature and inoculated with the oleaginous yeast.

\subsubsection{Lipid Production}

The simulation of the microbial oil production process is one of the most complex and delicate steps due to the lack of chemical reactions in the literature that universally describe the phenomenon. As reported by Koutinas et al. [42], two different stages (microbial growth and intracellular oil accumulation) during the fermentation process are considered to calculate mass balances with a good approximation [52]. Each stage is represented by a chemical reaction where the stoichiometric coefficients are calculated based on experimental results obtained by Li et al. [43] using glucose as carbon source and the oleaginous yeast Rhodosporidium toruloides Y4. Evans and Ratledge [55] studied the yeast Candida curvata $\mathrm{D}$, showing the possible and simultaneous use of glucose and xylose as carbon substrates in process fermentation. In order to use both glucose and xylose for microbial biomass production and subsequent lipid accumulation, cells of L. creatinivorum DBVPG 4794 are considered. The molecular equation for yeast $\left(\mathrm{C}_{4} \mathrm{H}_{6.5} \mathrm{O}_{1.9} \mathrm{~N}_{0.7}\right)$, necessary for the chemical reaction of the growth phase, is taken from Babel and Muller [56]. The nitrogen sources used during fermentation, such as peptone and yeast extract, are represented by amino acids $\left(\mathrm{C}_{5.35} \mathrm{H}_{9.85} \mathrm{O}_{2.45} \mathrm{~N}_{1.5}\right)$, whose components are described by an average molecular equation [42,56]. Unlike Koutinas et al. [42], we consider the lipid fraction of the yeast biomass (approximately 10\% w/w) indispensable for microbial growth, assuming that the triolein is the only triglyceride produced throughout fermentation process. The overall microbial biomass yield and lipid yield are $0.150 \mathrm{~g} / \mathrm{g}$ sugars and $0.135 \mathrm{~g} / \mathrm{g}$ sugars, respectively [52]. Experimental studies stress how all the carbon substrate is consumed during the fermentation process [43]. Reactions and their corresponding yields considered for microbial growth and microbial oil accumulation are given in Table 5. 
Table 5. Conversion for reaction considered in the lipid fermentation (R6); these reactions occur in series.

\begin{tabular}{|c|c|c|}
\hline Stoichiometry & Fractional Conversion of Component & Fractional Conversion \\
\hline $\begin{array}{c}\text { Glucose }+3.41 \text { Oxygen }+0.52 \text { Aminoacids } \\
\rightarrow 1.12 \text { Microbial Biomass }+3.75 \text { Carb } \\
\text { Dioxide }+4.41 \text { Water }+0.01 \text { Triolein }\end{array}$ & Glucose & 0.230 \\
\hline $\begin{array}{c}\text { Xylose }+2.41 \text { Oxygen }+0.52 \text { Aminoacids } \\
\rightarrow 1.12 \text { Microbial Biomass }+2.75 \text { Carb } \\
\text { Dioxide }+3.41 \text { Water }+0.01 \text { Triolein }\end{array}$ & Xylose & 0.190 \\
\hline $\begin{array}{c}\text { Glucose }+1.2 \text { Oxygen } \rightarrow 0.06 \text { Triolein }+ \\
2.58 \text { Carb. Dioxide }+2.88 \text { Water }\end{array}$ & Glucose & 0.510 \\
\hline $\begin{array}{c}\text { Xylose }+0.2 \text { Oxygen } \rightarrow 0.06 \text { Triolein }+ \\
\text { 1.58 Carb. Dioxide }+1.88 \text { Water }\end{array}$ & Xylose & 0.420 \\
\hline
\end{tabular}

Microbial growth and lipid accumulation at $25^{\circ} \mathrm{C}, 1 \mathrm{~atm}$, and $168 \mathrm{~h}$ of residence time.

Figure 3 shows the Aspen Plus flowsheet of lipid production (microbial growth and intracellular oil accumulation).

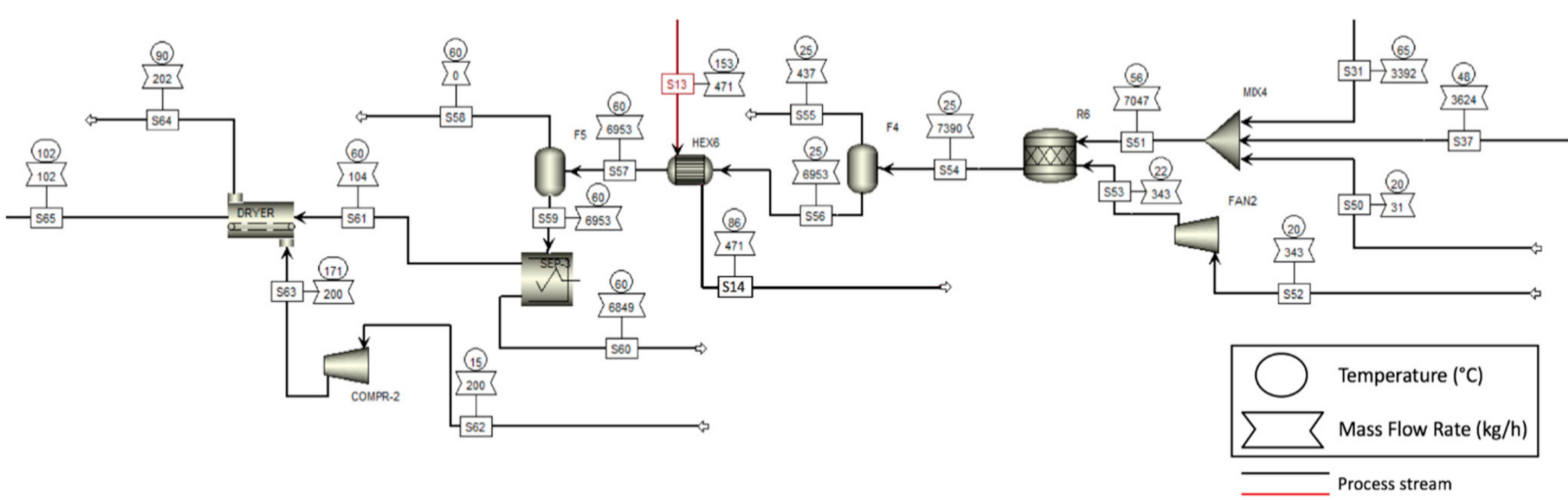

Figure 3. Flowsheet of lipid production as simulated using Aspen Plus.

The air stream (S52) is moved into the reactor by a fan (FAN2) and supplies the oxygen necessary to perform the microbial growth and the lipid accumulation reactions. The fermentation broth (S54) is initially subjected to a stage flash (F4) at atmospheric pressure to remove all traces of gas such as carbon dioxide and is heated (HEX6) to $60{ }^{\circ} \mathrm{C}$ to deactivate the enzymes in yeast cells. The necessary thermal energy is taken from the residual heat of the flash vapors (S13) generated during the steam-explosion pre-treatment. At this point, the microbial biomass (S59) containing the lipids is separated from fermentation liquid (S60) via a centrifuge filter (SEP-3). The moisture content of yeast cells (S65) is reduced to $2 \%$ using a convective dryer (DRYER) with the aim of increasing the biodiesel production efficiency during transesterification [42].

\subsubsection{Lipid Extraction}

Recent studies are focusing on microbial oil extraction methods, because the efficiency of biodiesel production process from microbial biomass is strongly connected to the oil extraction efficiency [57]. Here, we consider a solvent based lipid extraction method, which uses a methanol-chloroform mixture and has been successfully tested in several research activities [58,59]. Although this extraction method uses toxic and highly volatile solvents, it offers a high efficiency of extraction, and it requires lower energy inputs than mechanical techniques. Figure 4 shows the Aspen Plus flowsheet of the lipid fermentation, including the microbial growth and the microbial oil accumulation. 


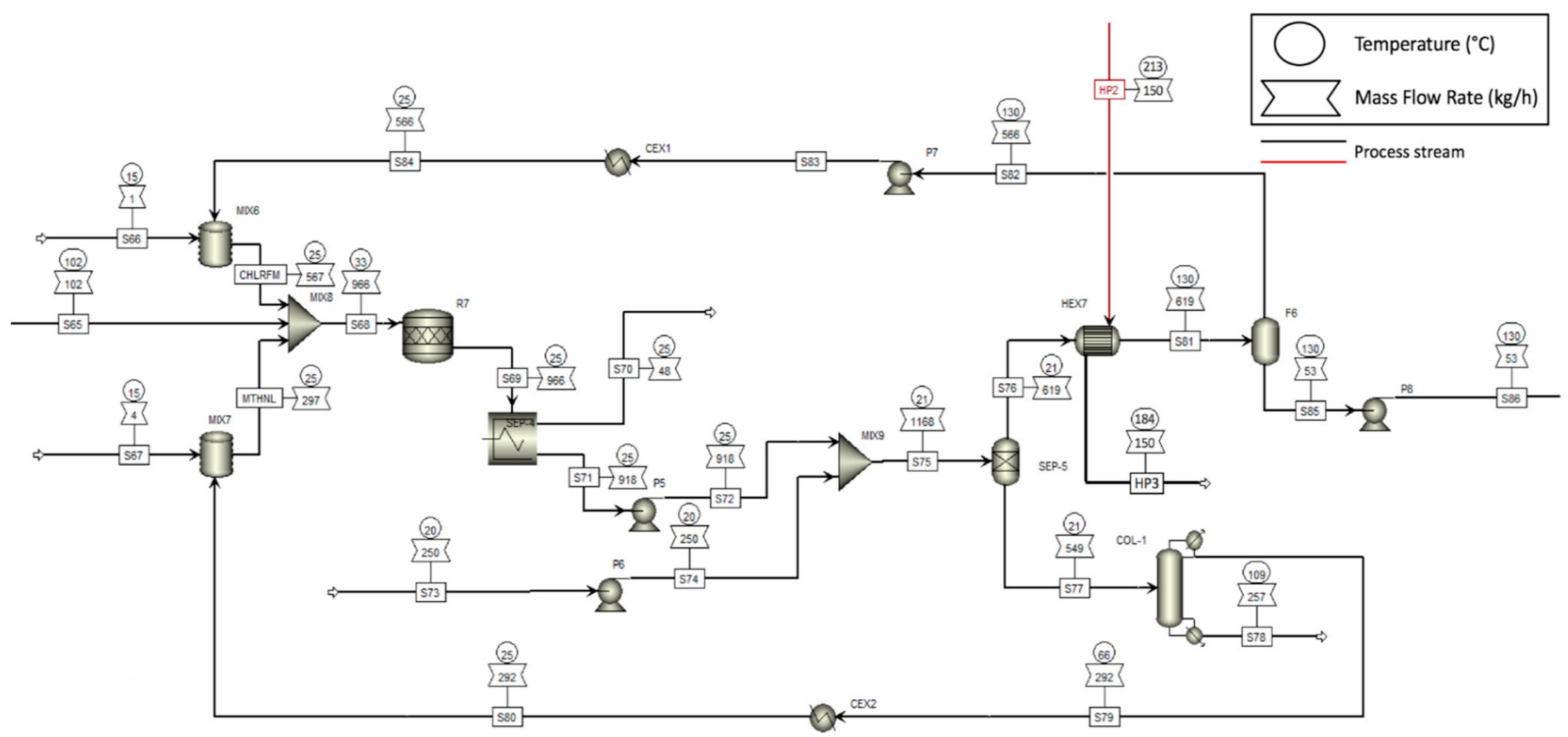

Figure 4. Flowsheet of lipid extraction with chloroform-methanol mixture as simulated using Aspen Plus.

Methanol (S67), chloroform (S66), and dry microbial biomass (S65) are mixed (MIX8) under environmental conditions in a mass ratio of 6:12:1 [58]. Lipid extraction phase is simulated in a stoichiometric reactor (R7), assuming that all the lipids contained in the microbial biomass are transformed in oil. The solid fraction (S70), mainly characterized by the yeast residual biomass and separated from the homogeneous mixture (S71) rich in solvents and oil via a centrifuge filter (SEP-4), could be recovered and sent to an anaerobic digestion plant to for biogas production [52]. However, this aspect is not considered due to an insignificant revenue. Liquid stream is mixed with process water (S73) in 4:1 ratio for hydrophilic/hydrophobic phases separation via a decanter (SEP-5). The large difference in the boiling points between oil and chloroform greatly facilitates their separation process, which is achieved with a single flash unit (F6) operating at $130{ }^{\circ} \mathrm{C}$ and $0.5 \mathrm{~atm}$. A sensibility analysis, where temperature variation was related to oil purity, is used to identify the best thermodynamic condition (minimum thermal load) considering a pressure of $0.5 \mathrm{~atm}$. Water-methanol separation requires a multi-stage distillation column (COL-1) simulated in the current flowsheet using a RadFrac block with a total condenser and a kettle reboiler. Twelve stages and a reflux ratio equal to 1 are imposed to produce a distillate with a mole purity of $98.5 \%$. A pressure drop of $0.4 \mathrm{~atm}$ between the boiler and the condenser is considered. Solvents (S79 and S82) are recycled, restoring their starting thermodynamic conditions, in order to decrease environmental impact and to reduce economic costs associated with their purchase.

\subsubsection{Trans-Esterification}

As evidenced by several authors, transesterification of triglycerides using sodium hydroxide as conventional homogeneous catalyst under a methanol-oil ratio of 6:1 represents the best condition for the transesterification process [3,19,60]. According to [60], 5\% of sodium hydroxide (based on oil) is used to avoid a reduction of the catalytic activity and therefore to increase conversion of methyl esters. Figure 5 shows the Aspen Plus flowsheet of the alkali-catalyzed process. 


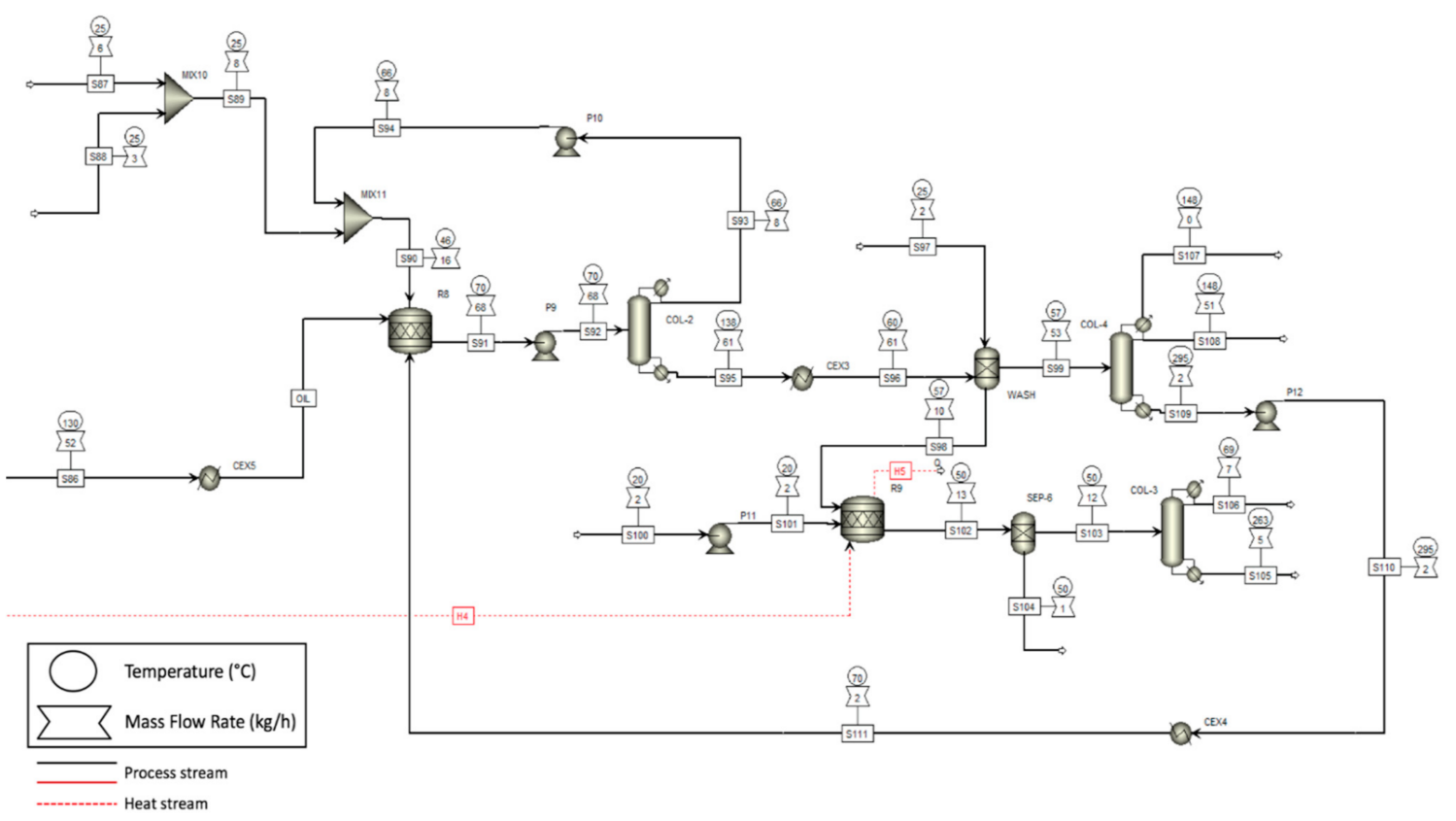

Figure 5. Flowsheet of transesterification as simulated using Aspen Plus.

A stoichiometric reactor block (R8), operating at $70{ }^{\circ} \mathrm{C}$ and $1 \mathrm{~atm}$, is used to simulate the transesterification process (Table 6) considering a single acid methyl ester to represent biodiesel product and a 95\% conversion of feedstock to model the reaction. Fresh methanol (S87) and sodium hydroxide (S88) are mixed under the atmospheric pressure prior to be conveyed to transesterification reactor (R8). Microbial oil (S86), completely composed of triolein, is cooled down to transesterification conditions before entering the reactor. Excess of methanol (S93) is recovered using a distillation column (COL-2) equipped with seven theoretical stages and a reflux ratio of 2. Vacuum distillation was used to keep the bottom temperature under $140{ }^{\circ} \mathrm{C}$. A design specification is implemented to obtain a methanol recovery (in mass) of $98.5 \%$ varying the distillate rate. The methyl esters formed and residual amount of triglycerides (S99) are separated from sodium hydroxide and glycerol (S98) via a washing column (WASH) with four theoretical stages fed by $2.5 \mathrm{~kg} / \mathrm{h}$ of fresh water (S97) [61,62]. The amounts of unconverted microbial oil, chloroform, methanol, and water in stream S99 are less than 4\%. All the glycerol remains in stream S98 together with methanol, sodium hydroxide, and water. Sodium hydroxide is removed (R9) by adding phosphoric acid (S100) to precipitate trisodium phosphate (Table 6), which is then separated from glycerol fraction by gravity separator (SEP-6). Neutralization of catalyst is performed using a stoichiometric reactor (R9) operating at $50{ }^{\circ} \mathrm{C}$ and $1.1 \mathrm{~atm}$. Glycerine purification is reproduced with a vacuum distillation column (COL-3) having six theoretical stages and a reflux ratio of 2 . A design specification is implemented to obtain a glycerol purity (in mass) of $99 \%$ varying the bottom rate. The bottom stream (S105), defined as a high-quality by-product, is totally composed of glycerol. Water and methanol are removed as distillate stream (S106) together with a small fraction of glycerol. Methyl-oleate purification is reproduced with a vacuum distillation column (COL-4) having eight theoretical stages, a partial condenser, and a reflux ratio of 2. COL-4 is operated under vacuum to avoid degradation of the biodiesel product thanks to a not particularly high temperature. Water and methanol are removed in stream S107 as vent gases. Biodiesel product, obtained in stream S108 as liquid distillate, has a mass purity of $99.8 \%$. The remaining amount of biodiesel remains at the bottom together with unconverted oil; this stream (S109) is cooled down (CEX4) before being directed again to the transesterification reactor (R8). 
Table 6. Conversion for reaction considered in the transesterification (R8) and neutralization of catalyst (R9).

\begin{tabular}{ccc}
\hline Stoichiometry & $\begin{array}{c}\text { Fractional Conversion of } \\
\text { Component }\end{array}$ & Fractional Conversion \\
\hline Triolein +3 Chloroform $\rightarrow 3$ M. Oleate + Glycerol & Triolein & 0.981 \\
3 Sod. Hydroxide + Phosp. Acid $\rightarrow$ Tris. Phospate +3 Water & Sod. Hydroxide & 1.000 \\
\hline
\end{tabular}

Transesterification at $70^{\circ} \mathrm{C}$ and $1 \mathrm{~atm}$. Neutralization of catalyst at $50{ }^{\circ} \mathrm{C}$ and $1 \mathrm{~atm}$.

\section{Results and Discussion}

\subsection{Simulation Results}

\subsubsection{Mass Balance}

This section shows the relevant information of the entire flowsheet, necessary to understand both the composition of the main streams and the total efficiency of the biorefinery scheme. Hydrolysis reactions are catalyzed using $28.56 \mathrm{~kg} / \mathrm{h}$ of dilute sulfuric acid (S5) and $544 \mathrm{~kg} / \mathrm{h}$ of high-pressure steam (S10). After the steam-explosion pre-treatment, $296.1 \mathrm{~kg} / \mathrm{h}$ of cellulose and $33.29 \mathrm{~kg} / \mathrm{h}$ of hemicellulose are recovered in the hydrolysate slurry (S11), respectively, the $95.4 \%$ and the $58.6 \%$ of the starting amounts. The flash vapors (S12 and S16), used to pre-heat the process water (S6), consist mainly of $512 \mathrm{~kg} / \mathrm{h}$ of steam and $6.86 \mathrm{~kg} / \mathrm{h}$ of furfural; $17.01 \mathrm{~kg} / \mathrm{h}$ of ammonia gas (S22) is introduced into the conditioning reactor to raise the $\mathrm{pH}$ of hydrolysate from 1 to $5-6$. The solid fraction of the slurry (S30) is diluted with $3375 \mathrm{~kg} / \mathrm{h}$ of fresh water and mixed with $1.879 \mathrm{~kg} / \mathrm{h}$ of Cellic Ctec 2 enzyme (S34) in order to promote the enzymatic hydrolysis reactions. The cellulose and xylan amounts are converted into 243.5 and $24.36 \mathrm{~kg} / \mathrm{h}$ of glucose and xylose, respectively. The solid fraction of the outlet stream (S36), rich in lignin and having a mass flow rate of $373.8 \mathrm{~kg} / \mathrm{h}$, is used to produce heat and electricity, while the sugar-rich syrup (S37), before being inoculate with the oleaginous microorganisms, is mixed with the liquid fraction of the hydrolysate slurry (S31) containing a fair amount of xylose. In detail, $257 \mathrm{~kg} / \mathrm{h}$ of glucose and $91.5 \mathrm{~kg} / \mathrm{h}$ of xylose take part in the fermentation reactions, where $31.1 \mathrm{~kg} / \mathrm{h}$ of amino acids (S50) are used to produce $47.1 \mathrm{~kg} / \mathrm{h}$ of microbial biomass and $52.3 \mathrm{~kg} / \mathrm{h}$ of lipids. To carry out the fermentation reactions, $72.0 \mathrm{~kg} / \mathrm{h}$ of oxygen (S52, corresponding to $342.8 \mathrm{~kg} / \mathrm{h}$ of air) is moved to the reactor (R6); this mass flow rate represents the stoichiometric requirement. The microbial biomass containing the lipids (S61) is separated from the inoculum (S60) and then treated with $281.7 \mathrm{~kg} / \mathrm{h}$ of methanol (S67 and S80) and $563.9 \mathrm{~kg} / \mathrm{h}$ of chloroform (S66 and S84) to extract $52.3 \mathrm{~kg} / \mathrm{h}$ of microbial oil (S69). After removal of microbial biomass (S70), a mixture composed mainly of oil, methanol, and chloroform (S72) is mixed with $250 \mathrm{~kg} / \mathrm{h}$ of fresh water (S73) to separate the hydrophilic/hydrophobic phases (S76 and S77). Over 99\% of the total chloroform (S82) is recovered and recirculated, while all the microbial oil (S86) is conveyed to the trans-esterification reactor. In this context, starting from $52.2 \mathrm{~kg} / \mathrm{h}$ of triolein, $51.5 \mathrm{~kg} / \mathrm{h}$ of methyl oleate and $5.33 \mathrm{~kg} / \mathrm{h}$ of glycerol are produced using $0.544 \mathrm{~kg} / \mathrm{h}$ of sodium hydroxide (S88) as homogeneous catalyst and $13.1 \mathrm{~kg} / \mathrm{h}$ of methanol (S87). Most of the methanol (98\%) is recovered (S93), cooled, and recirculated. Glycerol and sodium hydroxide (S98) are separated from methyl oleate and methanol (S99) through a washing column using $2.5 \mathrm{~kg} / \mathrm{h}$ of fresh water (S97).

Sodium hydroxide is removed by adding $0.444 \mathrm{~kg} / \mathrm{h}$ of phosphoric acid diluted with $1.77 \mathrm{~kg} / \mathrm{h}$ of fresh water (S100). Neutralization of catalyst produces $0.743 \mathrm{~kg} / \mathrm{h}$ of trisodium phosphate (S104), a solid by-product expelled by a gravity separator. The bottom liquid (S105) of the glycerol purification column has a mass flow rate of $5.19 \mathrm{~kg} / \mathrm{h}$; this amount is totally (99.9\% purity) composed of glycerol. The distillate liquid (S106), having a mass flow rate of $6.76 \mathrm{~kg} / \mathrm{h}$, contains $96.3 \%$ water.

The mixture of methyl oleate and methanol (S99) is subject to a distillation process where a partial condenser removes water and methanol (S107) as vent gases $(0.133 \mathrm{~kg} / \mathrm{h})$. Methyl oleate product (S108), obtained as liquid distillate, has a mass flow rate of $50.8 \mathrm{~kg} / \mathrm{h}$ and a mass purity of $99.8 \%$. The bottom liquid (S109), rich in unconverted oil and with a mass flow rate of $1.66 \mathrm{~kg} / \mathrm{h}$, is recirculated to the trans-esterification reactor. 


\subsubsection{Energy Balance}

The overall electricity demand, determined based on Aspen Plus process modeling results, was equal to $321.8 \mathrm{MWh} / \mathrm{y}$. In the developed process, the electricity consumption is estimated using different approaches. Electricity consumption of centrifugal pumps, compressors, and fans is directly obtained from the numerical model. The power required for size reduction of the starting lignocellulosic biomass is determined through the following equation:

$$
P=5.31 S^{2}-30.86 S+25.99
$$

where the specific energy requirement $(\mathrm{P})$, expressed in $\mathrm{kWh} /$ ton, is related to hammer mill screen size (S) [63]. It is assumed that the used feedstock to be equivalent to corn stover at a moisture content of $12 \%$. A specific energy consumption of $11.04 \mathrm{kWh} /$ ton is obtained considering a size reduction of $3.2 \mathrm{~mm}$, which is close to the results reported by Cadoche and Lopez [64]. A ratio of $1 \mathrm{kWh} / \mathrm{m}^{3}$ of feed flow rate is considered for centrifugal separators $[65,66]$. Figures 6 and 7 respectively, show the electricity and thermal demand of each main phase of the process with the corresponding percentage distribution in relation to total requirement.

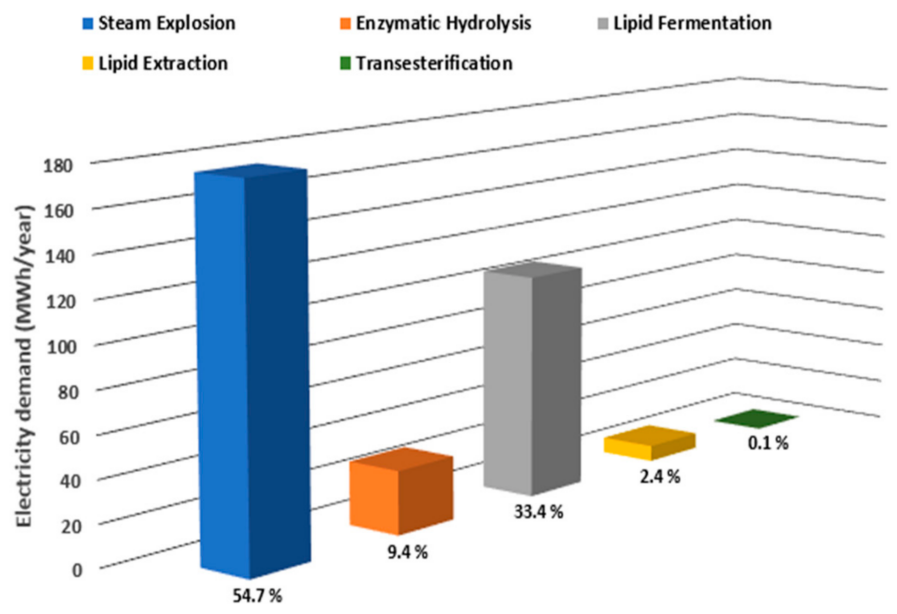

Figure 6. Distribution of electricity needs expressed in MWh/y and considering an operating period of $8000 \mathrm{~h} / \mathrm{y}$.

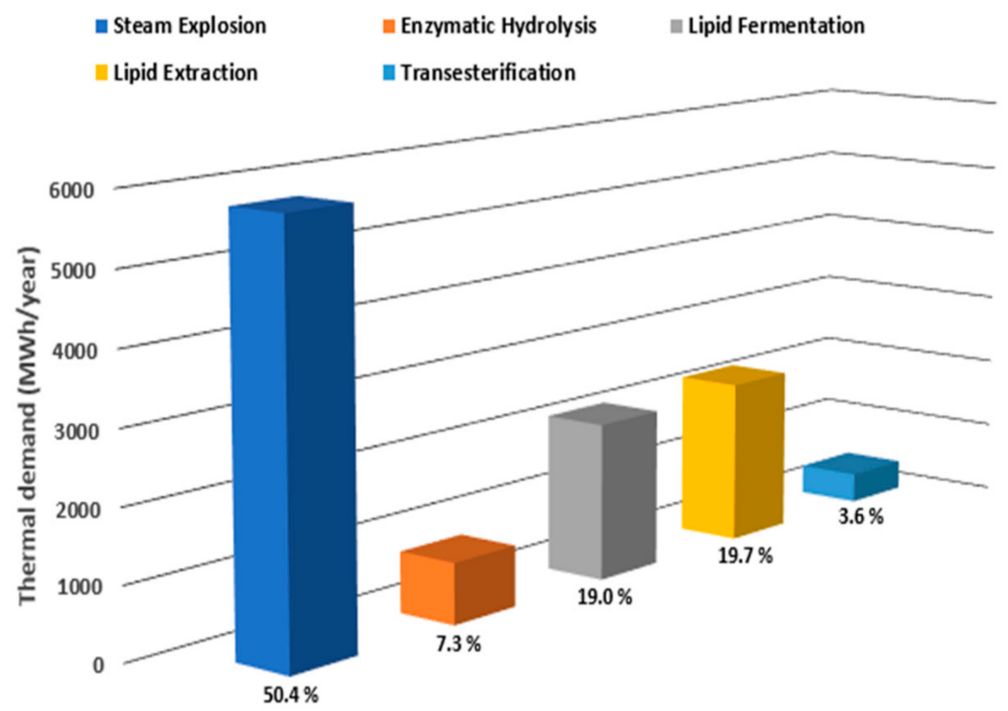

Figure 7. Distribution of thermal needs expressed in MWh/y and considering an operating period of $8000 \mathrm{~h} / \mathrm{y}$. 
The steam explosion pre-treatment represents the most energy-intensive section with a consumption of $175.9 \mathrm{MWh} / \mathrm{y}$. Here, the energy requirement for biomass grinding corresponds to about $60 \%(110.7 \mathrm{MWh} / \mathrm{y})$ of the total demand. Other significant contributions in the different process areas are given by centrifugal separators whose energy consumptions can reach 56.5 MWh/y (e.g., in fermentation stage) based on the flow rate processed.

The overall thermal demand is $11,474 \mathrm{MWh} / \mathrm{y}$, half of which (5778 MWh/y) is consumed in the high-temperature hydrothermal pre-treatment. The fermentation broth heating to deactivate the enzyme in yeast cells and the solvent recovery processes after lipid extraction require a significant heat input equal to $4441 \mathrm{MWh} / \mathrm{y}$. In the transesterification section, despite the use of three distillation columns, there is a small heat demand (about $418 \mathrm{MWh} / \mathrm{y}$ ) due to a low mass flow rate.

In this work, a total thermal integration is considered by employing in the process all the available heat sources [54,67]. Some by-product streams such as the flash vapors (S12 and S16) and the hydrolysate solid fraction (S36) are used to make the plant "thermalneutral" and therefore self-sufficient in energy. The flash vapors, mainly composed of water and furfural, first pre-heat the compressed process water (S7 and S8) up to $170{ }^{\circ} \mathrm{C}$ for the hydrothermal pre-treatment and then deactivate the enzymes in the yeast cells at $60{ }^{\circ} \mathrm{C}$ (S56). The combustion system produces $1118 \mathrm{~kW}$ (about $8944 \mathrm{MWh} / \mathrm{y}$ ) of heat (thermal content of the gas) and $500 \mathrm{~kg} / \mathrm{h}$ of superheated steam (S46) at $460{ }^{\circ} \mathrm{C}$ and $60 \mathrm{~atm}$, which is processed by a multistage turbine generator and then partially extracted (30\%) from the first stage to provide heat where needed. The choice of processing only $200 \mathrm{~kg} / \mathrm{h}$ of steam represents the right compromise to obtain output streams with the desired thermal characteristics. Flue gas (S41) is used to generate high pressure steam [54], which brings the pre-treatment steam (S10) to the operating temperature $\left(190{ }^{\circ} \mathrm{C}\right)$ and subsequently heats the triolein-chloroform (S76) mixture up to $130{ }^{\circ} \mathrm{C}$, thus promoting its separation. The heat of combustion (H1) satisfies the thermal energy requirements of the boilers in the distillation columns and of the reactors (see Table 7). It is worth noting that the heat duties significantly depend on temperature and mass flow rates. For example, the thermal energy necessary to glycerol and methyl oleate purification processes, differently from the methanol purification process, is low, as they treat small inlet mass flow rates. Distillation columns regulate the temperatures of their outlet streams (distillate and bottom fluid) and therefore the corresponding heat duty, varying the pressure in the boiler section. For this reason, in industrial applications, it is desirable to operate in vacuum conditions.

Table 7. Summary of energetic requirements satisfied with the heat of combustion.

\begin{tabular}{cc}
\hline Aspen Plus Block & Heat Duty (MWh/y) \\
\hline R1 & 2610 \\
R2 & 2202 \\
R4 & 838 \\
R9 & 13 \\
COL-1 (Reboiler) & 1826 \\
COL-2 (Reboiler) & 80 \\
COL-3 (Reboiler) & 115 \\
COL-4 (Reboiler) & 210 \\
Total & 7894 \\
\hline
\end{tabular}

The remaining part of the steam (i.e., not extracted) is processed in the second stage of the turbine to produce $87.1 \mathrm{~kW}(696.8 \mathrm{MWh} / \mathrm{y})$ used to power all the users in the plant. Sale of excess electricity, equal to $375 \mathrm{MWh} / \mathrm{y}$, generates additional revenue.

The amount of heat extracted to promote the cooling processes is equal to $7215 \mathrm{MWh} / \mathrm{y}$, whose percentage distribution between the main sections of the flowsheet is shown in Figure 8. Most of the heat removed (6499 MWh/y) is used to maintain the environmental conditions $\left(25^{\circ} \mathrm{C}\right)$ in the fermentation reactor and for solvents recovery operations during the microbial oil extraction. 


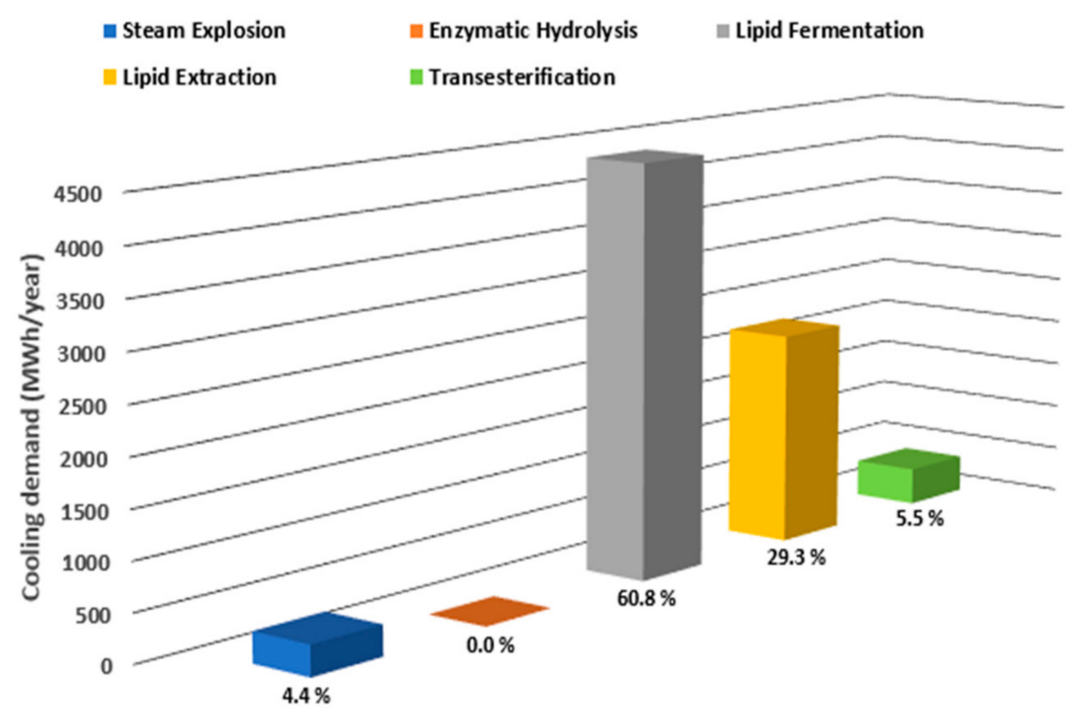

Figure 8. Distribution of removed heat expressed in $\mathrm{MWh} / \mathrm{y}$ and considering an operating period of $8000 \mathrm{~h} / \mathrm{y}$.

Cooling operations are simulated considering essentially two types of utilities: water and refrigerant 1 generation (propane). Refrigerant at $-25{ }^{\circ} \mathrm{C}$ is used to restore the environmental conditions of the recovered products, while cold water at $20^{\circ} \mathrm{C}$ is used in the condensers of the distillation columns and to maintain appropriate operating conditions in some stoichiometric reactors (Table 8).

Table 8. Summary of energetic requirements satisfied with the utilities.

\begin{tabular}{ccc}
\hline Aspen Plus Block & Utility ID & Utility Duty (MWh/y) \\
\hline R3 & Cooling water & 318.4 \\
R8 & Cooling water & 6.4 \\
COL-1 (Condenser) & Cooling water & 1515 \\
COL-2 (Condenser) & Cooling water & 59.2 \\
COL-3 (Condenser) & Cooling water & 108 \\
COL-4 (Condenser) & Cooling water & 22.9 \\
CEX3 & Cooling water & 183.2 \\
CEX4 & Cooling water & 2.4 \\
CEX5 & Cooling water & 13.6 \\
R6 & Refrigerant 1 & 4691 \\
R7 & Refrigerant 1 & 108 \\
CEX1 & Refrigerant 1 & 406 \\
CEX2 & Refrigerant 1 & 85.9 \\
\hline
\end{tabular}

\subsubsection{Economic Analysis}

The ultimate purpose of this chemical process simulation is to determine the economics of biodiesel production starting from microbial oil. This approach is used to understand biodiesel's potential in the marketplace when compared with traditional production processes and to guide future research in order to modify or optimize the production chain. In light of these considerations, the analysis developed is used to determine a fundamental economic parameter, such as the biodiesel production cost [68], whose value is directly related to feasibility project. As evidenced by Humbird et al. [44], the first step is to determine the total capital investment (TCI), which is strongly related to the total equipment cost, but also to several other indirect costs. The total equipment cost, representing the installation cost, takes into account all operations and materials needed to make the equipment functional (e.g., piping, foundation, wiring). In the current work, it is considered a simplified approach in which the purchased equipment cost, evaluated by Aspen PEA based on the 
construction material (carbon steel) and size, is increased by $60 \%$. This methodology differs from the common factored approach $[44,69,70]$, but it provides similar results. Proratable and field expenses, home office engineering and construction activities, project contingency, and other costs (start-up, permits, etc.) related to construction are computed to give the total indirect costs. Each of these economic items represents a certain fraction of the total equipment cost [44]. The fixed capital investment (FCI) is given by the sum of direct (TDC) and indirect (TIC) costs. Total capital cost, as reported in Equation (2), also includes working capital (WC), assumed to be $5 \%$ of the fixed capital investment $[44,53]$.

$$
\mathrm{TCI}=(\mathrm{TDC}+\mathrm{TIC})+\mathrm{WC}=\mathrm{FCI}+\mathrm{WC}
$$

The above mentioned economic considerations are summarized in Table 9.

Table 9. Project cost worksheet including total direct costs and total capital investment expressed in USD.

\begin{tabular}{cc}
\hline Equipment purchased cost & $4,836,000$ \\
Equipment installed cost & $7,737,600$ \\
Total direct costs (TDC) & $7,737,600$ \\
Prorateable expenses (10\% of TDC) & 773,760 \\
Field expenses (10\% of TDC) & 773,760 \\
Home office and construction fee (20\% of TDC) & $1,547,520$ \\
Project contingency (10\% of TDC) & 773,760 \\
Other costs (10\% of TDC) & 773,760 \\
Total indirect costs (TIC) & $4,642,560$ \\
Fixed capital investment (FCI) & $12,380,160$ \\
Working capital (5\% of FCI) & 619,008 \\
Total capital investment (TCI) & $12,999,168$ \\
\hline
\end{tabular}

The production cost (PC) is calculated by Equations (3) and (4) considering the manufacturing costs (MC), including total production costs (TPC), fixed costs (FC), byproduct sales (BS), and the yearly biodiesel production (PR) [71].

$$
\begin{gathered}
\mathrm{PC}=\mathrm{MC} / \mathrm{PR} \\
\mathrm{MC}=\mathrm{TPC}+\mathrm{FC}-\mathrm{BS}
\end{gathered}
$$

The total production costs (TPC) represents the sum of utilities, raw materials, operating labor, maintenance, supervision, operation charges, plant overhead, and general and administrative expenses ( $\mathrm{G} \& \mathrm{~A})$. Fixed costs include taxes and depreciation. It is assumed that the plant is depreciated over 10 years $(10 \%$ /year) via the straight-line depreciation method, and the taxes correspond to $15 \%$ of the total capital investment (TCI) [53]. Utilities and raw materials costs are chosen based on Aspen Plus database and literature references, respectively. Coolants cost adopted is related to amount of heat exported (Table 10). The electricity produced by the generator group is able to totally satisfy the energy demand of each section of the plant and so it is not necessary to withdraw from the power grid.

Table 10. Utilities used in the bio-refinery process.

\begin{tabular}{cccccc}
\hline Utilities & Utility Cost & Cost Unit & Rate & Rate Unit & Cost Per Hour (USD/h) \\
\hline Cooling water & $2.12 \times 10^{-7}$ & USD $/ \mathrm{kJ}$ & 813,395 & $\mathrm{~kJ} / \mathrm{h}$ & 0.17 \\
Refrigerant 1 & $2.71 \times 10^{-6}$ & $\mathrm{USD} / \mathrm{kJ}$ & 209,811 & $\mathrm{~kJ} / \mathrm{h}$ & 0.57 \\
\hline
\end{tabular}


The total cost of each raw material is listed in Table 11 and is determined based on Aspen Plus process modeling results. In this context, it is also essential to consider the residual value of some by-products such as glycerol and trisodium phosphate. Solvents used during the microbial oil extraction and the transesterification are recovered and recycled to minimize the costs associated to their purchase. A cost of waste liquid treatment equal to $0.10 \mathrm{USD} / \mathrm{t}$ is considered [42].

Table 11. Raw materials and byproduct prices.

\begin{tabular}{|c|c|c|c|}
\hline Raw Material & Amount (t/y) & Unit Cost (USD/t) & Total Cost (kUSD/y) \\
\hline Biomass $^{d}$ & 10,000 & 40 & 400 \\
\hline Sulfuric acid ${ }^{b}$ & 233.7 & 67 & 15.7 \\
\hline Ammonia ${ }^{b}$ & 136 & 50 & 6.8 \\
\hline Enzyme ${ }^{\mathrm{d}}$ & 6.6 & 3000 & 19.8 \\
\hline Amino acids ${ }^{c}$ & 250.4 & 800 & 200.3 \\
\hline Methanol ${ }^{\mathrm{b}}$ & 80.9 & 211 & 17.1 \\
\hline Chloroform ${ }^{b}$ & 8.3 & 211 & 1.8 \\
\hline Sodium hydroxide ${ }^{b}$ & 4.4 & 495 & 2.1 \\
\hline Potassium hydroxide ${ }^{b}$ & 9.76 & 890 & 8.7 \\
\hline Phosphoric acid ${ }^{b}$ & 3.5 & 804 & 2.8 \\
\hline Process water $\mathrm{b}$ & 55,136 & 0.20 & 11.1 \\
\hline Air & 7272 & - & - \\
\hline \multicolumn{4}{|l|}{ By-product } \\
\hline Glycerol $^{\mathrm{a}}$ & 41.6 & 1500 & 62.4 \\
\hline Trisodium phosphate ${ }^{a}$ & 5.9 & 500 & 2.9 \\
\hline \multicolumn{4}{|l|}{ Waste treatment } \\
\hline Liquid $^{\mathrm{c}}$ & 62,488 & 0.10 & 6.2 \\
\hline
\end{tabular}

${ }^{\mathrm{a}}[27],{ }^{\mathrm{b}}[42],{ }^{\mathrm{c}}[53],{ }^{\mathrm{d}}$ vendor quotation.

Manufacturing costs of biodiesel including total production and fixed costs are reported in Table 12. The staff consists of five operators (one for each main section of the plant) whose wage rate is assumed to be $20 \mathrm{USD} / \mathrm{h}$.

Table 12. Total production and fixed costs of biodiesel expressed in USD/year.

$\begin{array}{cc}\text { Utilities } & 266,720 \\ \text { Raw materials } & 386,200 \\ \text { Labor and supervision } & 800,000 \\ \text { Maintenance } & 210,384 \\ \text { Operating charges } & 200,000 \\ \text { Plant overhead } & 50,519 \\ \text { General and Administration } & 100,872 \\ \text { Total production cost (TPC) } & 2,014,695 \\ \text { Depreciation (10\% of TCI) } & 1,299,917 \\ \text { Taxes (15\% of TCI) } & 1,949,875 \\ \text { Total fixed costs (FC) } & 3,249,792 \\ \text { Byproduct sales (BS) } & 91,600 \\ \text { Manufacturing costs (MC) } & 5,199,187\end{array}$

Based on the results reported in Table 12 and the Equations (2)-(4), Table 1 the cost of biodiesel production from microbial oil is $12.8 \mathrm{USD} / \mathrm{kg}$. Koutinas et al. [42] estimated a biodiesel cost production of $5.9 \mathrm{USD} / \mathrm{kg}$, a value almost entirely attributed to microbial oil cost production (5.5 USD/kg), considering an annual production capacity of 10,000 t microbial oil and a price of glucose of $400 \mathrm{USD} / \mathrm{t}$. At a scale of $100 \mathrm{t} / \mathrm{y}$ microbial oil production, Parsons et al. [72] determined a minimum estimated selling price of about $14 \mathrm{USD} / \mathrm{kg}$ using sucrose and wheat straw and showed how this value was reduced to $7-8 \mathrm{USD} / \mathrm{kg}$ on scaling of $10,000 \mathrm{t} / \mathrm{y}$. The unitary production cost of microbial oil is significantly affected by the productivity of the microbial fermentation and the market 
price of the raw material used. It is evident that the fermentation stage where low microbial oil concentrations are achieved represents the most critical section of the entire plant. Although the oleaginous yeast adopted uses both glucose and xylose as carbon sources, the conversion yields imposed and the low plant capacity play a key role in the economic viability. The economic values found are very high when compared with the common chemicals and fuels, but the same is not true when high-value plant or animal fats are substituted from the potential utilization of these microbial oils. Richardson et al. [73] estimated that the cost of plant-derived lipids containing C-linolenic acid and therefore with similar composition to microbial oils produced by several oleaginous microorganisms to be $45-50 \mathrm{USD} / \mathrm{kg}$. Ratledge and Cohen [74] obtained a lipid production cost from algae of $21 \mathrm{USD} / \mathrm{kg}$, while Alabi et al. [75] reported a variable cost between $7.64 \mathrm{USD} / \mathrm{L}$ and 14.44 USD/L. However, low lipid production cost (about $2.25 \mathrm{USD} / \mathrm{kg}$ ) from algae can also be achieved under particular conditions [76].

A sensitivity analysis is performed to identify effects of the microbial fermentation productivity and of the plant capacity on the economy of the project. The biodiesel cost production is estimated considering first a lipid yield of $22 \%$ and then a plant capacity of $100,000 \mathrm{t} / \mathrm{y}$ lignocellulosic biomass. According to many scholars, the lipid yield on the glucose consumed can reach $22 \%$ under ideal conditions [74,77,78]. An increase in biodiesel production rate of $62.9 \%$ is obtained by optimizing the fermentation stage. Against manufacturing cost practically unchanged, the biodiesel cost production equal to $7.88 \mathrm{USD} / \mathrm{kg}$ is subject to a reduction of $38.4 \%$ compared to the base case studied. The standard flowsheet is modified in order to consider the influence of a different mass flow rate (capacity plant) assumed to be 100,000 t/y on the same economic item. An exponential scaling expression, given by Equation (5), is used to evaluate the new purchased equipment cost:

$$
\mathrm{C}=\mathrm{C}_{0} \times\left(\mathrm{S} / \mathrm{S}_{0}\right)^{\mathrm{n}}
$$

where $C$ is the cost of the process unit, $C_{0}$ is the cost of the reference unit, $S$ is the capacity of the process unit, $\mathrm{S} 0$ is the capacity of the reference unit, and $\mathrm{n}$ is the capacity scaling exponent, assumed equal to 0.67 [79] for all equipment. The turbo-generator group, being able to satisfy the electrical and thermal demands of each block thanks to the increase of the processed flow rate, keeps utilities cost limited. On the other hand, the large amount of feedstock treated requires a greater number of qualified personnel, considered to be 10 operators per shift. In conclusion, a biodiesel production cost of $5.91 \mathrm{USD} / \mathrm{kg}$ (equal to a reduction of $53.8 \%$ compared the initial case) is determined. Under this perspective, the plant shows very promising results if compared with literature studies based on the same production process [42].

A biodiesel production cost of $3.63 \mathrm{USD} / \mathrm{kg}$ is found by combining the ideal lipid yield with the new plant size. The economic values obtained are not yet comparable with the vegetable oil prices [42], characterized by considerable price swings with upward trending, but this may be evidence that biodiesel production from microbial oil could become a competitive scenario to vegetables oils.

Furthermore, in order to increase the economic sustainability of the process, the use of microbial oil, without the transesterification step, in triple blends with organic solvents and fossil diesel as alternative fuel for diesel engines could be analyzed in a future work. This strategy allows the improvement of the fuel properties of triglycerides, and it has actually been analyzed only with vegetable oils $[80,81]$.

\section{Conclusions}

This paper evaluated the technical and economic feasibility on an industrial scale of biodiesel production from of microbial oil using cardoon stalks as raw material. The process was designed and rigorously simulated through a thermo-chemical model, employing technical data from laboratory results and pilot plant operation. A detailed study of a plant processing 10,000 $\mathrm{t}$ of feedstock per year and producing $406.4 \mathrm{t}$ of biodiesel per year was 
carried out to analyze the performances and to investigate the production costs of biodiesel through the use of the yeast L. creatinivorum DBVPG 4794.

The economic evaluation results indicated that microbial biodiesel production cost is equal to $12.8 \mathrm{USD} / \mathrm{kg}$, much higher than the current market price of biodiesel (about $0.9 \mathrm{USD} / \mathrm{kg}$ ). In this scenario, the total capital investment was about 13 million USD and the total operating cost was about 2 million USD.

However, we demonstrated that the plant capacity has a significant effect on the unit production cost, which could be decreased by over $50 \%$, down to $5.9 \mathrm{USD} / \mathrm{kg}$, sizing the plant to obtain and annual production of 100,000 $\mathrm{t}$ of feedstock.

We also evaluated the effect of lipid yield (from $13.5 \%$ to $22 \%$ ) to the economic feasibility, and we demonstrated that the production cost could be further reduced to $3.63 \mathrm{USD} / \mathrm{kg}$ for a production plant with a capacity of 100,000 $\mathrm{t} /$ year.

The results of this techno-economic assessment provide insights on the economic competitiveness of producing microbial biodiesel from cardoon stalks via the microbial oil route.

Author Contributions: Conceptualization: M.B.; formal analysis: D.B.; funding acquisition: S.U.; investigation: M.C.; methodology: M.B., M.C. and D.B.; project administration: S.U. and P.B.; resources: S.U. and P.B.; supervision: M.B. and D.B.; writing-original draft: M.C.; writing一review and editing: M.B., I.B. and D.B. All authors have read and agreed to the published version of the manuscript.

Funding: The study has received financial support by the Ministry of Education, University and Research (MIUR)-Italy, in the frame of the project PON 2015-2020: "ARS01_00985 BIOFEEDSTOCK— Development of Integrated Technological Platforms for Residual Biomass Exploitation".

Institutional Review Board Statement: Not applicable.

Informed Consent Statement: Not applicable.

Data Availability Statement: Data sharing not applicable.

Conflicts of Interest: The authors declare no conflict of interest.

\section{References}

1. Felizardo, P.; Neiva Correia, M.J.; Raposo, I.; Mendes, J.F.; Berkemeier, R.; Bordado, J.M. Production of biodiesel from waste frying oils. Waste Manag. 2006, 26, 487-494. [CrossRef]

2. Pinzi, S.; Pilar dorado, M. Feedstocks for advanced biodiesel production. In Advances in Biodiesel Production; Elsevier: Amsterdam, The Netherlands, 2012; pp. 69-90.

3. Zhang, Y.; Dubé, M.A.; McLean, D.D.; Kates, M. Biodiesel production from waste cooking oil: 1. Process design and technological assessment. Bioresour. Technol. 2003. [CrossRef]

4. Manaf, I.S.A.; Rahim, M.H.A.; Govindan, N.; Maniam, G.P. A first report on biodiesel production from Aglaia korthalsii seed oil using waste marine barnacle as a solid catalyst. Ind. Crops Prod. 2018, 125, 395-400. [CrossRef]

5. Tamilalagan, A.; Singaram, J.; Rajamohan, S. Generation of biodiesel from industrial wastewater using oleaginous yeast: Performance and emission characteristics of microbial biodiesel and its blends on a compression injection diesel engine. Environ. Sci. Pollut. Res. 2019, 26, 11371-11386. [CrossRef] [PubMed]

6. Koutinas, A.A.; Papanikolaou, S. Biodiesel production from microbial oil. In Handbook of Biofuels Production; Elsevier: Amsterdam, The Netherlands, 2011; pp. 177-198. ISBN 9780857090492.

7. Han, S.; Kim, G.-Y.; Han, J.-I. Biodiesel production from oleaginous yeast, Cryptococcus sp. by using banana peel as carbon source. Energy Rep. 2019, 5, 1077-1081. [CrossRef]

8. Patel, A.; Arora, N.; Pruthi, V.; Pruthi, P.A. Biological treatment of pulp and paper industry effluent by oleaginous yeast integrated with production of biodiesel as sustainable transportation fuel. J. Clean. Prod. 2017, 142, 2858-2864. [CrossRef]

9. Deeba, F.; Patel, A.; Arora, N.; Pruthi, V.; Pruthi, P.A.; Negi, Y.S. Amaranth seeds (Amaranthus palmeri L.) as novel feedstock for biodiesel production by oleaginous yeast. Environ. Sci. Pollut. Res. 2018, 25, 353-362. [CrossRef]

10. Papanikolaou, S.; Diamantopoulou, P.; Chatzifragkou, A.; Philippoussis, A.; Aggelis, G. Suitability of Low-Cost Sugars as Substrates for Lipid Production by the Fungus Thamnidium elegans. Energy Fuels 2010, 24, 4078-4086. [CrossRef]

11. Leiva-Candia, D.E.; Pinzi, S.; Redel-Macías, M.D.; Koutinas, A.; Webb, C.; Dorado, M.P. The potential for agro-industrial waste utilization using oleaginous yeast for the production of biodiesel. Fuel 2014, 123, 33-42. [CrossRef]

12. Gouda, M.K.; Omar, S.H.; Aouad, L.M. Single cell oil production by Gordonia sp. DG using agro-industrial wastes. World J. Microbiol. Biotechnol. 2008, 24, 1703-1711. [CrossRef] 
13. Chebbi, H.; Leiva-Candia, D.; Carmona-Cabello, M.; Jaouani, A.; Dorado, M.P. Biodiesel production from microbial oil provided by oleaginous yeasts from olive oil mill wastewater growing on industrial glycerol. Ind. Crops Prod. 2019, 139, 111535. [CrossRef]

14. Yoo, C.; Jun, S.Y.; Lee, J.Y.; Ahn, C.Y.; Oh, H.M. Selection of microalgae for lipid production under high levels carbon dioxide. Bioresour. Technol. 2010. [CrossRef] [PubMed]

15. Meng, X.; Yang, J.; Xu, X.; Zhang, L.; Nie, Q.; Xian, M. Biodiesel production from oleaginous microorganisms. Renew. Energy 2009. [CrossRef]

16. Guil-Guerrero, J.; Navarro-Juárez, R.; López-Martínez, J.; Campra-Madrid, P.; Rebolloso-Fuentes, M. Functional properties of the biomass of three microalgal species. J. Food Eng. 2004, 65, 511-517. [CrossRef]

17. Cho, H.U.; Park, J.M. Biodiesel production by various oleaginous microorganisms from organic wastes. Bioresour. Technol. 2018, 256, 502-508. [CrossRef]

18. Rashid, U.; Anwar, F. Production of Biodiesel through Base-Catalyzed Transesterification of Safflower Oil Using an Optimized Protocol. Energy Fuels 2008, 22, 1306-1312. [CrossRef]

19. Glisic, S.; Skala, D. The problems in design and detailed analyses of energy consumption for biodiesel synthesis at supercritical conditions. J. Supercrit. Fluids 2009, 49, 293-301. [CrossRef]

20. Vlad, E.; Bildea, C.S.; Pleşu, V.; Marton, G.; Bozga, G. Process design of biodiesel production from rapeseed oil. Chem. Eng. Trans. 2010. [CrossRef]

21. Meher, L.C.; Vidya Sagar, D.; Naik, S.N. Technical aspects of biodiesel production by transesterification-A review. Renew. Sustain. Energy Rev. 2006. [CrossRef]

22. Tasselli, G.; Filippucci, S.; Borsella, E.; D’Antonio, S.; Gelosia, M.; Cavalaglio, G.; Turchetti, B.; Sannino, C.; Onofri, A.; Mastrolitti, S.; et al. Yeast lipids from cardoon stalks, stranded driftwood and olive tree pruning residues as possible extra sources of oils for producing biofuels and biochemicals. Biotechnol. Biofuels 2018. [CrossRef]

23. Kahr, H.; Pointner, M.; Krennhuber, K.; Wallner, B.; Jäger, A. Lipid production from diverse oleaginous yeasts from steam exploded corn cobs. Agron. Res. 2015, 13, 318-327.

24. Yu, X.; Zheng, Y.; Dorgan, K.M.; Chen, S. Oil production by oleaginous yeasts using the hydrolysate from pretreatment of wheat straw with dilute sulfuric acid. Bioresour. Technol. 2011, 102, 6134-6140. [CrossRef]

25. Zhang, J.; Zhou, H.; Liu, D.; Zhao, X. Pretreatment of lignocellulosic biomass for efficient enzymatic saccharification of cellulose. In Lignocellulosic Biomass to Liquid Biofuels; Elsevier: Amsterdam, The Netherlands, 2019; pp. 17-65. ISBN 9780128159361.

26. Wiklund, A. The genus Cynara L. (Asteraceae-Cardueae). Bot. J. Linn. Soc. 1992, 109, 75-123. [CrossRef]

27. Torres, C.M.; Ríos, S.D.; Torras, C.; Salvadó, J.; Mateo-Sanz, J.M.; Jiménez, L. Sustainability analysis of biodiesel production from Cynara Cardunculus crop. Fuel 2013, 111, 535-542. [CrossRef]

28. Cravero, V.; Martin, E.; Crippa, I.; Anido, F.L.; García, S.M.; Cointry, E. Fresh biomass production and partitioning of aboveground growth in the three botanical varieties of Cynara cardunculus L. Ind. Crops Prod. 2012, 37, 253-258. [CrossRef]

29. Ciancolini, A.; Alignan, M.; Pagnotta, M.A.; Vilarem, G.; Crinò, P. Selection of Italian cardoon genotypes as industrial crop for biomass and polyphenol production. Ind. Crops Prod. 2013, 51, 145-151. [CrossRef]

30. Angelini, L.G.; Ceccarini, L.; Nassi o Di Nasso, N.; Bonari, E. Long-term evaluation of biomass production and quality of two cardoon (Cynara cardunculus L.) cultivars for energy use. Biomass Bioenergy 2009, 33, 810-816. [CrossRef]

31. Shatalov, A.A.; Pereira, H. Biorefinery of Energy Crop Cardoon(Cynara cardunculus L.)-Hydrolytic Xylose Production as Entry Point to Complex Fractionation Scheme. J. Chem. Eng. Process Technol. 2011, 2, 8. [CrossRef]

32. Galanopoulos, C.; Giuliano, A.; Barletta, D.; Zondervan, E. An integrated methodology for the economic and environmental assessment of a biorefinery supply chain. Chem. Eng. Res. Des. 2020, 160, 199-215. [CrossRef]

33. Mabrouk, A.; Erdocia, X.; Alriols, M.G.; Labidi, J. Economic analysis of a biorefinery process for catechol production from lignin. J. Clean. Prod. 2018, 198, 133-142. [CrossRef]

34. Aspen Technology Inc. Aspen Plus ®User Guide; Aspen Technology Inc.: Bedford, MA, USA, 2000.

35. Facci, A.L.; Ubertini, S. Meta-heuristic optimization for a high-detail smart management of complex energy systems. Energy Convers. Manag. 2018, 160, 341-353. [CrossRef]

36. Loreti, G.; Facci, A.L.; Baffo, I.; Ubertini, S. Combined heat, cooling, and power systems based on half effect absorption chillers and polymer electrolyte membrane fuel cells. Appl. Energy 2019, 235, 747-760. [CrossRef]

37. García, A.; Alriols, M.G.; Llano-Ponte, R.; Labidi, J. Energy and economic assessment of soda and organosolv biorefinery processes. Biomass Bioenergy 2011, 35, 516-525. [CrossRef]

38. Giuliano, A.; Poletto, M.; Barletta, D. Process Design of a Multi-Product Lignocellulosic Biorefinery. In Computer Aided Chemical Engineering; Elsevier B.V.: Amsterdam, The Netherlands, 2015; Volume 37, pp. 1313-1318.

39. Meramo, S.; Ojeda, K.A.; Sánchez, E.L. Integrated Biorefinery from Corn Waste Biomass: A Case Study in the North of Colombia. Int. J. Chem. Tech. Res. 2018, 11, 33-40.

40. Phan, A.N.; Phan, T.M. Biodiesel production from waste cooking oils. Fuel 2008, 87, 3490-3496. [CrossRef]

41. van Kasteren, J.M.N.; Nisworo, A.P. A process model to estimate the cost of industrial scale biodiesel production from waste cooking oil by supercritical transesterification. Resour. Conserv. Recycl. 2007, 50, 442-458. [CrossRef]

42. Koutinas, A.A.; Chatzifragkou, A.; Kopsahelis, N.; Papanikolaou, S.; Kookos, I.K. Design and techno-economic evaluation of microbial oil production as a renewable resource for biodiesel and oleochemical production. Fuel 2014, 116, 566-577. [CrossRef] 
43. Li, Y.; Zhao, Z.K.; Bai, F. High-density cultivation of oleaginous yeast Rhodosporidium toruloides Y4 in fed-batch culture. Enzyme Microb. Technol. 2007, 41, 312-317. [CrossRef]

44. Humbird, D.; Davis, R.; Tao, L.; Kinchin, C.; Hsu, D.; Aden, A.; Schoen, P.; Lukas, J.; Olthof, B.; Worley, M.; et al. Process Design and Economics for Biochemical Conversion of Lignocellulosic Biomass to Ethanol: Dilute-Acid Pretreatment and Enzymatic Hydrolysis of Corn Stover; U.S. Department of Energy Office of Scientific and Technical Information: Oak Ridge, TN, USA, 2011.

45. Wooley, R.J.; Putsche, V. Development of an ASPEN PLUS Physical Property Database for Biofuels Components; U.S. Department of Energy Office of Scientific and Technical Information: Oak Ridge, TN, USA, 1996.

46. Li, Q.; Du, W.; Liu, D. Perspectives of microbial oils for biodiesel production. Appl. Microbiol. Biotechnol. 2008, 80, 749-756. [CrossRef]

47. Zhu, L.Y.; Zong, M.H.; Wu, H. Efficient lipid production with Trichosporonfermentans and its use for biodiesel preparation. Bioresour. Technol. 2008, 99, 7881-7885. [CrossRef]

48. ASPEN PLUS Chemical Engineering Applications; Wiley: Hoboken, NJ, USA, 2017; ISBN 9788578110796.

49. Bell, J.C.; Messerly, R.A.; Gee, R.; Harrison, A.; Rowley, R.L.; Wilding, W.V. Ternary liquid-liquid equilibrium of biodiesel compounds for systems consisting of a methyl ester + glycerin + water. J. Chem. Eng. Data 2013. [CrossRef]

50. Luyben, W.L. Distillation Design and Control Using AspenTM Simulation; John Wiley \& Sons, Inc.: Hoboken, NJ, USA, 2006; ISBN 9780471785255.

51. Bertini, A.; Gelosia, M.; Cavalaglio, G.; Barbanera, M.; Giannoni, T.; Tasselli, G.; Nicolini, A.; Cotana, F. Production of Carbohydrates from Cardoon Pre-Treated by Acid-Catalyzed Steam Explosion and Enzymatic Hydrolysis. Energies 2019, $12,4288$. [CrossRef]

52. Barbanera, M.; Castellini, M.; Tasselli, G.; Turchetti, B.; Cotana, F.; Buzzini, P. Prediction of the environmental impacts of yeast biodiesel production from cardoon stalks at industrial scale. Fuel 2021, 283, 118967. [CrossRef]

53. Ashraf, M.T.; Schmidt, J.E. Process simulation and economic assessment of hydrothermal pretreatment and enzymatic hydrolysis of multi-feedstock lignocellulose-Separate vs combined processing. Bioresour. Technol. 2018, 249, 835-843. [CrossRef]

54. Damartzis, T.; Michailos, S.; Zabaniotou, A. Energetic assessment of a combined heat and power integrated biomass gasificationinternal combustion engine system by using Aspen Plus ${ }^{\circledR}$. Fuel Process. Technol. 2012, 95, 37-44. [CrossRef]

55. Evans, C.T.; Ratledge, C. A comparison of the oleaginous yeast, Candida curvata, grown on different carbon sources in continuous and batch culture. Lipids 1983, 18, 623-629. [CrossRef]

56. Babel, W.; Muller, R. Correlation between cell composition and carbon conversion efficiency in microbial growth: A theoretical study. Appl. Microbiol. Biotechnol. 1985, 22. [CrossRef]

57. Ranjith Kumar, R.; Hanumantha Rao, P.; Arumugam, M. Lipid Extraction Methods from Microalgae: A Comprehensive Review. Front. Energy Res. 2015, 2. [CrossRef]

58. Peralta-Ruiz, Y.; González-Delgado, A.-D.; Kafarov, V. Evaluation of alternatives for microalgae oil extraction based on exergy analysis. Appl. Energy 2013, 101, 226-236. [CrossRef]

59. Kumar, L.R.; Yellapu, S.K.; Tyagi, R.D.; Drogui, P. Cost, energy and GHG emission assessment for microbial biodiesel production through valorization of municipal sludge and crude glycerol. Bioresour. Technol. 2020, 297, 122404. [CrossRef]

60. Xie, W.; Huang, X.; Li, H. Soybean oil methyl esters preparation using NaX zeolites loaded with $\mathrm{KOH}$ as a heterogeneous catalyst. Bioresour. Technol. 2007, 98, 936-939. [CrossRef]

61. Demirbaş, A. Biodiesel fuels from vegetable oils via catalytic and non-catalytic supercritical alcohol transesterifications and other methods: A survey. Energy Convers. Manag. 2003, 44, 2093-2109. [CrossRef]

62. Dorado, M.P.; Ballesteros, E.; Mittelbach, M.; López, F.J. Kinetic Parameters Affecting the Alkali-Catalyzed Transesterification Process of Used Olive Oil. Energy Fuels 2004, 18, 1457-1462. [CrossRef]

63. Mani, S.; Tabil, L.G.; Sokhansanj, S. Grinding performance and physical properties of wheat and barley straws, corn stover and switchgrass. Biomass Bioenergy 2004, 27, 339-352. [CrossRef]

64. Cadoche, L.; López, G.D. Assessment of size reduction as a preliminary step in the production of ethanol from lignocellulosic wastes. Biol. Wastes 1989, 30, 153-157. [CrossRef]

65. Szepessy, S.; Thorwid, P. Low Energy Consumption of High-Speed Centrifuges. Chem. Eng. Technol. 2018, 41, 2375-2384. [CrossRef]

66. Milledge, J.J.; Heaven, S. Disc Stack Centrifugation Separation and Cell Disruption of Microalgae: A Technical Note. Environ. Nat. Resour. Res. 2011, 1. [CrossRef]

67. Martis, R.; Al-Othman, A.; Tawalbeh, M.; Alkasrawi, M. Energy and Economic Analysis of Date Palm Biomass Feedstock for Biofuel Production in UAE: Pyrolysis, Gasification and Fermentation. Energies 2020, 13, 5877. [CrossRef]

68. Sotoft, L.F.; Rong, B.-G.; Christensen, K.V.; Norddahl, B. Process simulation and economical evaluation of enzymatic biodiesel production plant. Bioresour. Technol. 2010, 101, 5266-5274. [CrossRef]

69. Peters, M.S.; Timmerhaus, K.D.; West, R.E. Plant Design and Economics for Chemical Engineers, 5th ed.; McGraw-Hill: New York, NY, USA, 2003; ISBN 9789896540821.

70. Garrett, D.E. Chemical Engineering Economics; Springer: Dordrecht, The Netherlands, 1989; ISBN 978-94-011-6546-4.

71. Vinet, L.; Zhedanov, A. A 'missing' family of classical orthogonal polynomials. J. Phys. A Math. Theor. 2011, 44, 085201. [CrossRef] 
72. Parsons, S.; Abeln, F.; McManus, M.C.; Chuck, C.J. Techno-economic analysis (TEA) of microbial oil production from waste resources as part of a biorefinery concept: Assessment at multiple scales under uncertainty. J. Chem. Technol. Biotechnol. 2019, 94, 701-711. [CrossRef]

73. Richardson, J.W.; Johnson, M.D.; Outlaw, J.L. Economic comparison of open pond raceways to photo bio-reactors for profitable production of algae for transportation fuels in the Southwest. Algal Res. 2012, 1, 93-100. [CrossRef]

74. Ratledge, C.; Cohen, Z. Microbial and algal oils: Do they have a future for biodiesel or as commodity oils? Lipid Technol. 2008, 20, 155-160. [CrossRef]

75. Alabi, A.; Tampier, M.; Bibeau, E. Microalgae Technologies E Processes for Biofuels-Bioenergy Production in British Columbia: Current Technology, Suitability \& Barriers to Implementation; Final Report Submitted to British Columbia Innovation Council; British Columbia Innovation Council: Vancouver, BC, Canada, 2009.

76. Davis, R.; Aden, A.; Pienkos, P.T. Techno-economic analysis of autotrophic microalgae for fuel production. Appl. Energy 2011, 88, 3524-3531. [CrossRef]

77. Ratledge, C.; Wynn, J.P. The Biochemistry and Molecular Biology of Lipid Accumulation in Oleaginous Microorganisms. Adv. Appl. Microb. 2002, 1-52. [CrossRef]

78. Papanikolaou, S.; Aggelis, G. Biotechnological valorization of biodiesel derived glycerol waste through production of single cell oil and citric acid by Yarrowia lipolytica. Lipid Technol. 2009, 21, 83-87. [CrossRef]

79. Remer, D.S.; Chai, L.H. Design cost factors for scaling-up engineering equipment. Chem. Eng. Prog. 1990, 86, 77-82.

80. Aguado-Deblas, L.; Hidalgo-Carrillo, J.; Bautista, F.M.; Luna, D.; Luna, C.; Calero, J.; Posadillo, A.; Romero, A.A.; Estevez, R. Acetone Prospect as an Additive to Allow the Use of Castor and Sunflower Oils as Drop-In Biofuels in Diesel/Acetone/Vegetable Oil Triple Blends for Application in Diesel Engines. Molecules 2020, 25, 2935. [CrossRef]

81. Aguado-Deblas, L.; Hidalgo-Carrillo, J.; Bautista, F.M.; Luna, C.; Calero, J.; Posadillo, A.; Romero, A.A.; Luna, D.; Estévez, R. Biofuels from Diethyl Carbonate and Vegetable Oils for Use in Triple Blends with Diesel Fuel: Effect on Performance and Smoke Emissions of a Diesel Engine. Energies 2020, 13, 6584. [CrossRef] 